\title{
Isolation and characterisation of metallothionein from the clam Ruditapes decussatus
}

\author{
Dina C. Simes ${ }^{\mathrm{a}}$, Maria João Bebianno ${ }^{\mathrm{a}, *}$, José J.G. Moura ${ }^{\mathrm{b}}$ \\ ${ }^{a}$ CIMA, Faculdade de Ciências do Mar e do Ambiente, Universidade do Algarve, Campus de Gambelas, 8000 Faro, Portugal \\ ${ }^{\mathrm{b}}$ Departamento de Química, Centro de Química Fina e Biotecnologia, Faculdade de Ciências e Tecnologia, Universidade Nova de Lisboa, \\ 2825-114 Monte da Caparica, Portugal
}

Received 11 March 2002; received in revised form 8 October 2002; accepted 25 October 2002

\begin{abstract}
Metallothioneins (MT) were obtained after purification from metal-exposed clams (Ruditapes decussatus) using gelpermeation and ion-exchange chromatography. Four cadmium-metallothioneins (CdMTs) were resolved by ionexchange chromatography and they all had similar molecular weights, high cadmium content and an absorption spectra indicative of the presence of characteristic $\mathrm{Cd}-\mathrm{S}$ aggregates. The $\mathrm{NH}_{2}$-terminal sequence suggests the presence of at least two class I clam MT isoforms. For the other two putative clam CdMTs isolated, the results of the amino acid determination were inconclusive. One was slightly contaminated and the other one had a blocked $\mathrm{NH}_{2}$-terminal. These clam metalothioneins contain glycine, which seems to be a common feature of molluscan MT family and exhibited more similarity to oysters than to mussels. Further investigation on the inducibility of these isoforms will be necessary if clams are to be used as biomarkers of metal exposure.
\end{abstract}

(C) 2002 Elsevier Science B.V. All rights reserved.

Keywords: Metallothionein; Clam; Ruditapes decussatus; Cd; Toxicity

\section{Introduction}

Despite their discovery by Margoshes and Vallee more than 40 years ago in 1957, metallothioneins (MTs) are still an interesting matter of research (see Kagi, 1993; Roesijadi, 1993; Langston et al., 1998; Dabrio et al., 2002 for reviews). These proteins are low-molecular mass $(6-7 \mathrm{kDa}$; $57-75$ amino acids), cysteine-rich proteins (18-20

\footnotetext{
* Corresponding author. Tel.: +351-289-800-923; fax: + 351-289-818-353

E-mail address: mbebian@ualg.pt (M.J. Bebianno).
}

cysteines per molecule) lacking aromatic amino acids (Kagi and Shaffer, 1988). They are distinguished by an exceptionally high content of $\mathrm{d}^{10}$ metal ions $\left(\mathrm{Zn}^{2+}, \mathrm{Cd}^{2+}\right.$ and $\left.\mathrm{Cu}^{+}\right)$forming characteristic metal-thiolate clusters through the sulphur atoms of all the cysteine groups that compose the protein, with thiolate groups acting both as a terminal and bridging metal ions (Dabrio et al., 2002). MT is a cytosolic protein found in a variety of prokaryotic and eukaryotic organisms including vertebrates, invertebrates, plants and microorganisms where the occurrence of the amino acid sequence Cys-Xaa-Cys is a character- 
istic feature of these proteins (Hammer, 1986; Kagi and Kojima, 1987a,b). MTs occurs in several isoforms which may differ from each other by only a few amino acid positions and by different isoelectric points and hydrophobicity (Kagi, 1993; Dabrio et al., 2002). The existence of different MT isoforms with different roles has also been a matter of scientific interest (Nordberg, 1998).

The function of this protein and of its isoforms is still a matter under discussion. MTs have traditionally thought to be involved in the regulation of essential trace metals, such as copper and zinc and in the detoxification of essential and nonessential metals. More central functions are attributed to this proteins such as the intracellular scavenging of free radicals in protecting cells against oxidative stress (Chubatsu and Meneghini, 1993) and zinc-mediated gene regulation (Zeng et al., 1991a,b). The exposure of an organism to toxic factors, such as $\mathrm{d}^{10}$ metal ions, induces MT expression in different tissues. Therefore, these proteins could be used for exposure assessment in free-living organisms and in environmental pollution assessment.

Mammalian MTs have been widely studied and many of the proteins have been sequenced. However, so far, only the primary structure of a few MTs from aquatic invertebrate tissues has been elucidated, either by amino acid sequence analysis or by deduction from MT cDNAs or mRNAs. Among these are the MTs from crabs (Pedersen et al., 1994; Brouwer et al., 1989), mussel (Mackay et al., 1993; Khoo and Patel, 1999) snail (Berger et al., 1995), sea urchin (Wang et al., 1994) and oyster (Roesijadi et al., 1989).

Two dimensional NMR and X-ray crystallography have made considerable progress in the determination of the structure of MT in mammals and crabs. These studies revealed that in mammals, MT is a monomeric dumbbell shaped protein with seven metal ions located in two separate metal thiolate clusters. The metal ions in both clusters are tetrahedrally co-ordinated by both bridging the thiolate ligands. The three-metal cluster is located in the $\mathrm{N}$-terminal $\beta$-domain and the four metal clusters in the $\mathrm{C}$-terminal $\alpha$-domain (Braun et al., 1992; Robbins et al., 1991; Dabrio et al., 2002). The other liquid phase NMR structures are those of equinoderme (Riek et al., 1999) and crab (Narula et al., 1995). Both structures revealed a monomeric protein composed of two globular domains binding a four- and a three-metal cluster in the equinodermal MT and two three metalclusters in the crustacean MT.

Previous studies indicated that in the clam Ruditapes decussatus, a suspension-feeding bivalve mollusc widely distributed, MT was induced after exposure to Cd (Bebianno et al., 1993, 1994). However, the full characterisation of this protein was still unknown. Therefore, the aim of the present study was to characterise, identify, purify and sequence the $\mathrm{NH}_{2}$-terminal of the MTs isoforms from the clam $R$. decussatus.

\section{Materials and methods}

\subsection{Reagents and materials}

Superdex 75 and Resource Q were purchased from Pharmacia LKB Biotechnology $\mathrm{AB}$ and Whatman ${ }^{\circledR}$, respectively. Reverse-phase $\mathrm{C} 18 \mathrm{mi}-$ crobore cartridges and reagents employed for Nterminal sequencing and HPLC analysis were purchased from Applied Biosystems ${ }^{\circledR}$. PMSF, DTT and Trizma base were from Sigma Chemical Co. All other chemicals and reagents were from Merck or from Sigma Chemical Co.

\subsection{Animals and cadmium exposure}

$R$. decussatus (shell length $29-34 \mathrm{~mm}$ ) were collected from Ria Formosa lagoon (South of Portugal) in October 1996 and maintained in 101 tanks at $17{ }^{\circ} \mathrm{C}$ with aerated seawater contaminated with $100 \mu \mathrm{g} \mathrm{Cd}^{2+} 1^{-1}$, salinity $34 \%$, for 20 days. The water in the tank was changed three times a week and 200 clams were used for tissue preparation, MT purification and metal content.

\subsection{Tissue preparation}

Bivalves were frozen at $-80{ }^{\circ} \mathrm{C}$. The digestive part was dissected $(45.14 \pm 0.01 \mathrm{~g})$ and homogenised immediately (IKA, model Ultra-Turrax T- 
25 ) in seven volumes of $20 \mathrm{mM}$ Tris $-\mathrm{HCl}$ buffer (pH 8.6 with $0.1 \mathrm{mM}$ PMSF and $0.5 \mathrm{mM}$ DTT) (7 min, $4{ }^{\circ} \mathrm{C}$ ), followed by centrifugation at $30000 \times$ $g\left(1 \mathrm{~h}, 4{ }^{\circ} \mathrm{C}\right)$. The supernatant was treated at $80{ }^{\circ} \mathrm{C}$ for $13 \mathrm{~min}$ in an orbital shaker, to precipitate the high molecular weight proteins and centrifuged at $30000 \times g\left(1 \mathrm{~h}, 4{ }^{\circ} \mathrm{C}\right)$.

The final supernatant extract was concentrated by ultrafiltration (Amicon, YM1) and stored at $80{ }^{\circ} \mathrm{C}$ in $3 \mathrm{ml}$ aliquots.

\subsection{Metallothionein purification}

Aliquots of the heat-treated homogenate were fractionated by gel-permeation chromatography (Superdex 75, Pharmacia). The elution was made with Tris- $\mathrm{HCl} 20 \mathrm{mM}$, pH 8.6 containing $150 \mathrm{mM}$ $\mathrm{NaCl}, 0.1 \mathrm{mM}$ PMSF and $0.5 \mathrm{mM}$ DTT. For each fraction, the absorbance at $254 \mathrm{~nm}$ was measured and cadmium concentration analysed by graphite furnace atomic absorption spectrometry (Zeeman ${ }^{\circledR}$ Varian SpectrAA 300/400). The presence in the eluate of proteins with high sulfhydryl content was investigated further by differential pulse polarography (Methrom 646, model 646 SMDE) as described by Bebianno and Langston (1989). The column $(26 \mathrm{~mm} \times 60 \mathrm{~cm})$ had been calibrated with the following markers of known molecular mass: blue dextran $(2000 \mathrm{kDa})$, bovine albumin $(67 \mathrm{kDa})$, ovalbumin $(43 \mathrm{kDa})$, dessulfoferredoxin (D. gigas) $(28 \mathrm{kDa})$, ribonuclease A $(13.7 \mathrm{kDa})$, cytochrome $C(12.4 \mathrm{kDa})$ and rubredoxin $(6 \mathrm{kDa})$. Cadmium-enriched fractions containing material with molecular weight similar to rabbit MT I (Sigma) and with high sulfhydryl content, were pooled, concentrated and dialysed by ultrafiltration (Amicon, YM1). This pooled sample was fractionated further by ion exchange chromatography (Resource Q, Pharmacia) equilibrated with Tris- $\mathrm{HCl} 10 \mathrm{mM}$ pH 8 as starting buffer, followed by an increasing step gradient from 10 to $800 \mathrm{mM}$ (see Fig. 2). The eluate obtained was fractionated while the UV absorbance at $254 \mathrm{~nm}$ was monitored. The main cadmium binding fractions obtained were then pooled and concentrated (Amicon, YM1).

The proteins eluted from ion exchange chromatography were assayed for homogeneity by elec- trophoresis under denaturing conditions (SDSPAGE) in mini-slab gels $(70 \times 80 \times 1 \mathrm{~mm})$. Stacking gels were $0.1 \%$ SDS, $5 \%$ polyacrylamide, and separating gels were $0.1 \%$ SDS and $17.5 \%$ polyacrylamide. Gels were stained by the Coomassie Blue G-250/H3PO4 protein staining method (Mitra et al., 1994) and by the silver-stain method (Blum et al., 1987).

\subsection{Determination of metal content}

The cadmium content was obtained by graphite furnace atomic absorption spectrometry (Zeeman ${ }^{\circledR}$ Varian SpectrAA 300/400).

\subsection{Molecular weight estimation of the protein}

The Superdex 75 column used for purification was calibrated with Molecular Weight markers, range 6-67 $\mathrm{kDa}$ (as described above) and the relative elution volumes used for molecular weight estimation of cadmium binding proteins (CdMTs) from the clam $R$. decussatus. For comparison, the samples were subject to $17.5 \%$ SDS-polyacrylamide gel electrophoresis (PAGE) calibrated with Molecular Weight markers, range 6.214-16.949 $\mathrm{kDa}$ (Pharmacia). To avoid the formation of disulfide bonds $\beta$-mercaptoethanol was used in the buffer.

\section{7. $\mathrm{NH}_{2}$-terminal amino acid sequence}

The sequence of the desalted samples obtained from the ionic exchange purification was determined by subjecting the intact polypeptide chain to Edman degradation. Standard procedures recommended by the manufacturer were used for the analyses in an automatic Applied Biosystems (model 477A). All chemicals used were from Applied Biosystems and were prepared as recommended. The separation and identification of the amino acid phenylthiohydantoin derivatives was performed in an on-line HPLC reverse-phase $\mathrm{C}_{18}$ model 130A. 


\section{Results}

\subsection{Purification and characterisation of the metallothioneins}

R. decussatus in the presence of $100 \mu \mathrm{g} \mathrm{Cd}^{2+}$ $1^{-1}$ accumulates the metal preferentially in the cytosol. The chromatogram obtained after the separation on Superdex 75 of the clam heat-treated cytosolic extract (Fig. 1) shows that approximately $95 \%$ of total Cd eluted with a retention time similar to that of MT-1 from rabbit liver (Sigma) showing also high absorbance at $254 \mathrm{~nm}$. The catalytic wave (at $-1.54 \mathrm{~V}$ ) of the thawed clam extract, obtained by differential pulse polarography, confirms also the existence of proteins containing a high sulphydryl residue content (data not shown) with similar characteristics to the MT catalytic wave previously described by Bebianno et al. (1993) for different tissues of this species. The apparent molecular weight of the protein, calculated after calibration of the column with standard molecular markers, was 13700 Da. This CdMT fraction was further purified by ion-exchange chromatography and the elution profiles at 254 and $280 \mathrm{~nm}$ (Fig. 2) showed four peaks (CdMT-1,

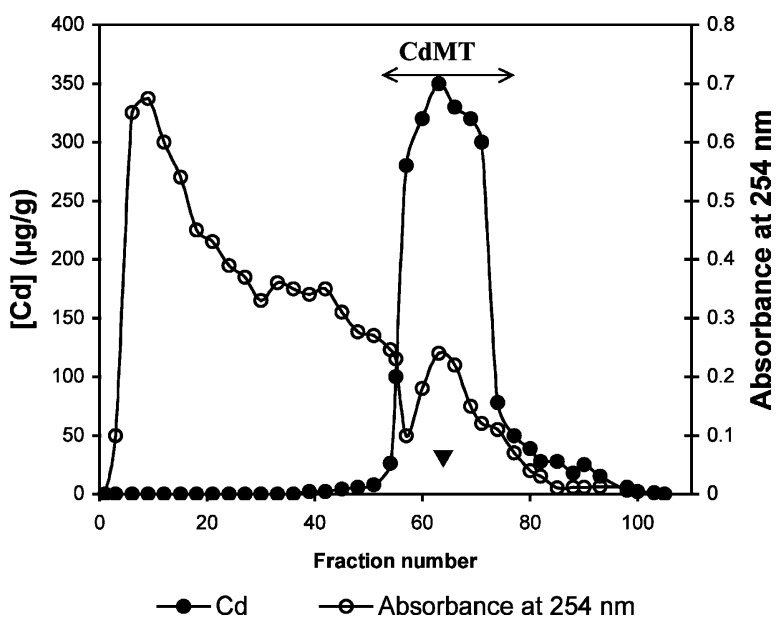

Fig. 1. Chromatographic Superdex 75 profile of heat-treated cytosol of cadmium exposed clams. The elution was made with $20 \mathrm{mM}$ Tris- $\mathrm{HCl}, \mathrm{pH} 8.6$ (150 mM NaCl; $0.1 \mathrm{mM}$ PMSF; 0.5 mM DTT) buffer. The double arrow shows the fractions pooled for further processing. The triangle shows the elution position of the MT standard.
CdMT-2, CdMT-3 and CdMT-4). The homogeneity of these fractions was demonstrated by 17.5\% SDS-PAGE. Fraction CdMT-1, CdMT-2 and CdMT-3 showed a single band with a $R_{\mathrm{f}}$ similar to the $R_{\mathrm{f}}$ of MT-1 from rabbit liver (Sigma, Fig. 3). Although some high molecular weight proteins were present, due probably to inefficient heat-denaturation procedure, all the samples were pure enough at this stage, to exhibit metal-binding properties consistent with the expected relationship between MT SH groups and metals.

The ultraviolet absorption spectra obtained for the four $\mathrm{Cd}^{2+}-\mathrm{MT}$ s obtained from the Resource Q chromatography is characteristic of MTs (Kagi et al., 1974). With a high $A_{254} / A_{280}$ ratio, a broad absorption envelope and a shoulder centred at about $254 \mathrm{~nm}$ typical of $\mathrm{Cd}$-thiolate complexes (Vasak, 1991). The low aromatic content (absorption at $280 \mathrm{~nm}$ ) was also evident (Fig. 2). On acidification (dissociation of the $\mathrm{Cd}-\mathrm{S}$ bond) the absorbance at $254 \mathrm{~nm}$ disappeared when protons displace $\mathrm{Cd}$, yielding the low $\mathrm{pH}$ spectrum of apoMT. This result was confirmed for all four $\mathrm{Cd}^{2+}$ binding proteins but is only presented for CdMT-1 in Fig. 4. The calibration of the PAGE with standard markers gave a molecular weight of 7.328 Da for all three fractions (CdMT-1, CdMT-2 and CdMT-3) but is only presented for Cd-BP1 in Fig. 5. Fraction CdMT-4 showed, in the same conditions, a faster electrophoretic mobility towards the anode. The molecular weight obtained by PAGE is significantly lower than that obtained for gel chromatography. The existence of disulfide bonds was ruled out because the electrophoretic behaviour of the protein was similar in the presence and absence of $\beta$-mercaptoethanol (results not shown).

Although the absorption coefficient of molluscs apo-MT could be higher once the amino acid content of these proteins are higher (72-75 amino acids) than mammalian ones, the protein concentration was calculated using the absorption coefficient of the mammalian (62 amino acids) apo-MT in $100 \mathrm{mM} \mathrm{HCl}$ at $220 \mathrm{~nm}\left(\varepsilon=48200 \mathrm{M}^{-1} \mathrm{~cm}^{-1}\right)$, as described by Vasak (1991), because no absorption coefficient have been reported for molluscs apo-MT. Protein concentration along with the $\mathrm{Cd}$ content determined in each fraction and the 


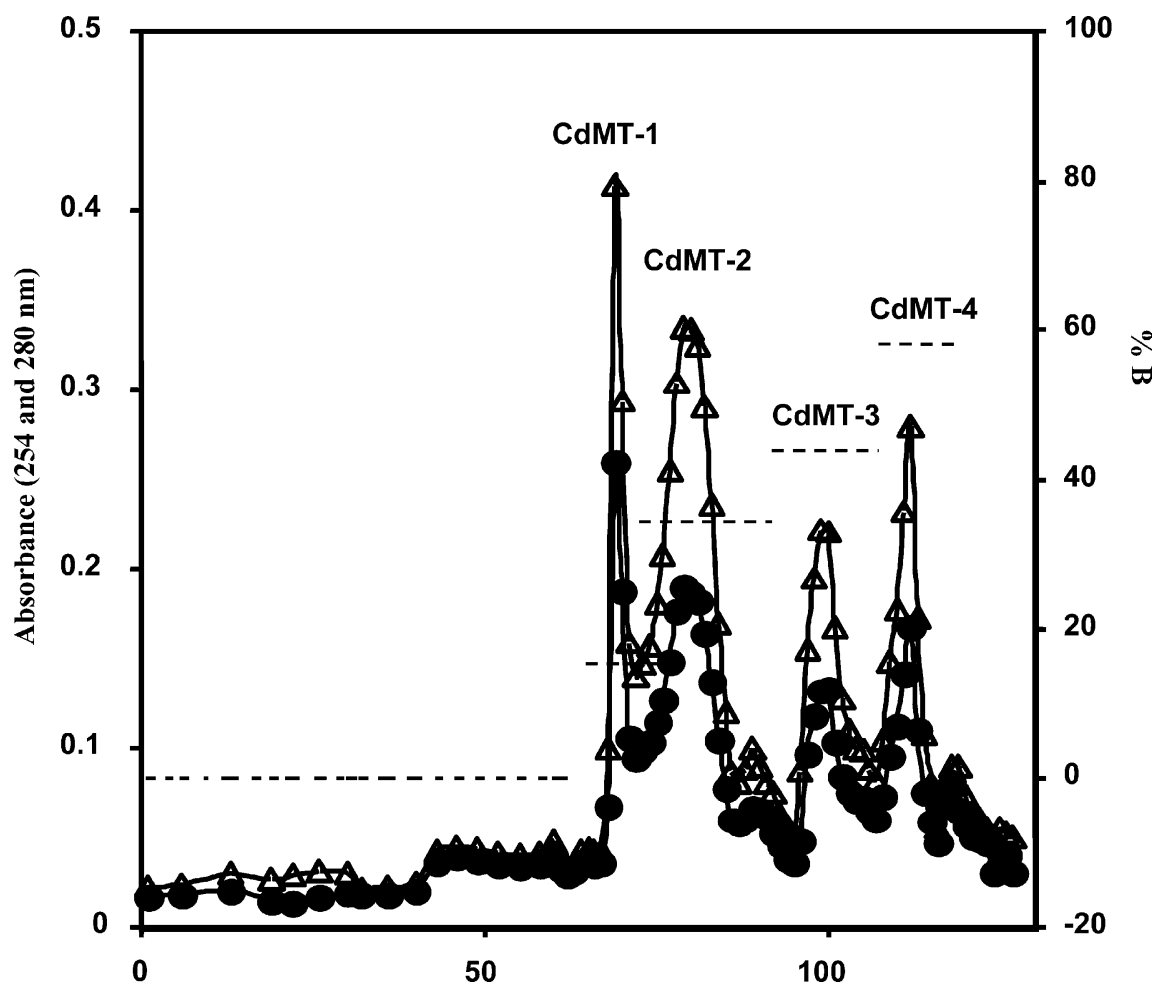

Fraction number

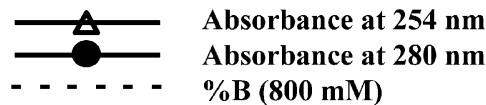

Fig. 2. Ion exchange chromatography of main cadmium-containing peak (CdMT) of Fig. 1 on Resource Q. Elution gradient was carried out as described in Section 2. The double arrow denotes effluent fractions pooled for further characterised. The dashed line indicate the increasing concentration of Tris $-\mathrm{HCl}$ buffer gradient from 10 to $800 \mathrm{mM}$.

stoichiometry of $\mathrm{Cd}^{2+}$ binding to $R$. decussatus MT are presented in Table 1.

After desalting and drying, the four samples were subject to an $\mathrm{NH}_{2}$-terminal sequenciation. The CdMT-1 sequence was determined through residue 19 (Table 2). This region included glycine at the $\mathrm{NH}_{2}$-terminal amino acid and two Cys-XYCys sequences considered characteristic of MT. CdMT-2 was only sequenced through residue 5 and is probably an isoform of the latter in which the aspartic acid was substituted by a glutamic acid. CdMT-3 was contaminated with sample CdMT-2 and CdMT-4 was blocked at the $\mathrm{NH}_{2}-$ terminal having a NG-sequence, a known phenomenon due to the cyclisation of ammonia.
Table 1

Stoichiometry of metal in Cd-MTs of the clam $R$. decussatus

\begin{tabular}{llll}
\hline & $\mathrm{MT}^{\mathrm{a}}\left(\mathrm{mol} \times 10^{6}\right)$ & $\mathrm{Cd}^{\mathrm{b}}\left(\mathrm{mol} \times 10^{6}\right)$ & $\mathrm{Cd}-\mathrm{MT}$ \\
\hline CdMT-1 & 0.02 & 0.160 & 8.0 \\
CdMT-2 & 0.01 & 0.076 & 7.6 \\
CdMT-3 & 0.01 & 0.062 & 6.2 \\
CdMT-4 & ${ }_{-}^{\mathrm{c}}$ & 0.054 & $-{ }^{\mathrm{c}}$
\end{tabular}

a Calculated from the absorption of the apoprotein $\left(\varepsilon_{220}=\right.$ $48200 \mathrm{M}^{-1} \mathrm{~cm}^{-1}$ ) and the value of molecular weight calculated by calibration on gel SDS-PAGE (7328 Da).

$\mathrm{b}$ Calculated by furnace atomic absorption spectrophotometry.

c This value was not calculated because of the abnormal electrophoretic behaviour on SDS-PAGE (see text). 


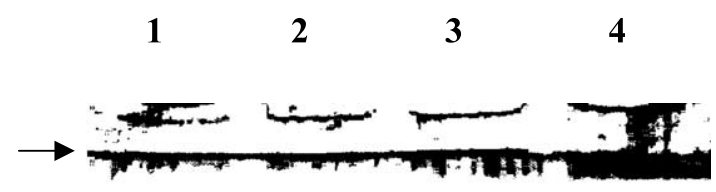

Fig. 3. SDS-PAGE of clam cadmium-binding proteins purified by ion-exchange chromatography (CdMT-1; CdMT-2; CdMT-3) and MT-1 from rabbit liver (Sigma). Stained by the silver-stain method as described in Blum et al. (1987). Lane-1, CdMT-1; Lane-2, CdMT-2; Lane-3, CdMT-3; Lane-4, MT-1 from rabbit liver (Sigma).

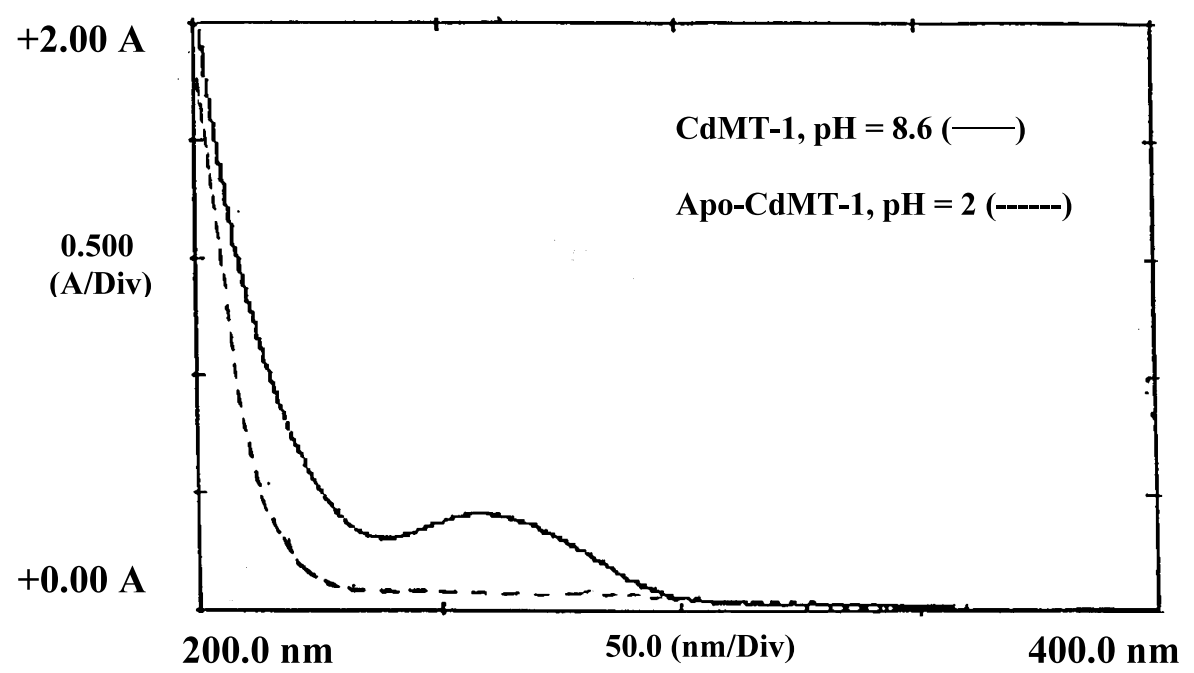

Fig. 4. Ultraviolet absorption spectra of one isoform of MT (CdMT-1) in the presence and absence of cadmium. CdMT-1 in Tris-HCl $10 \mathrm{mM}, \mathrm{pH} 8.6$ (_- ) and apo-MT in $100 \mathrm{mM} \mathrm{HCl}(--------)$.

\section{Discussion}

In many species MT occurs in several isoforms that differ substantially in amino acid composition. All mammals tissues examined thus far usually contain two major class I MT isoforms, designated as MT-I and MT-II (Kagi and Kojima, 1987a). So far, only a few sequences of molluscan MTs have been characterised in the mussels Mytilus edulis (Mackay et al., 1993), Perna viridis (Khoo and Patel, 1999) and the oyster Crassostrea virginica (Roesijadi et al., 1989; Unger et al., 1991).

In other marine organisms namely the mussel M. edulis (Mackay et al., 1993) two families of MT differing in size, were present with apparent molecular weight of around 10 and $20 \mathrm{kDa}$. Our results of gel permeation chromatography agree with those for the oyster $C$. virginica (Roesijadi et al., 1989) and the crab Carcinus maenas (Pedersen et al., 1994) who showed only a single peak at the $10-13 \mathrm{kDa}$ position. In fact the results of Super- 


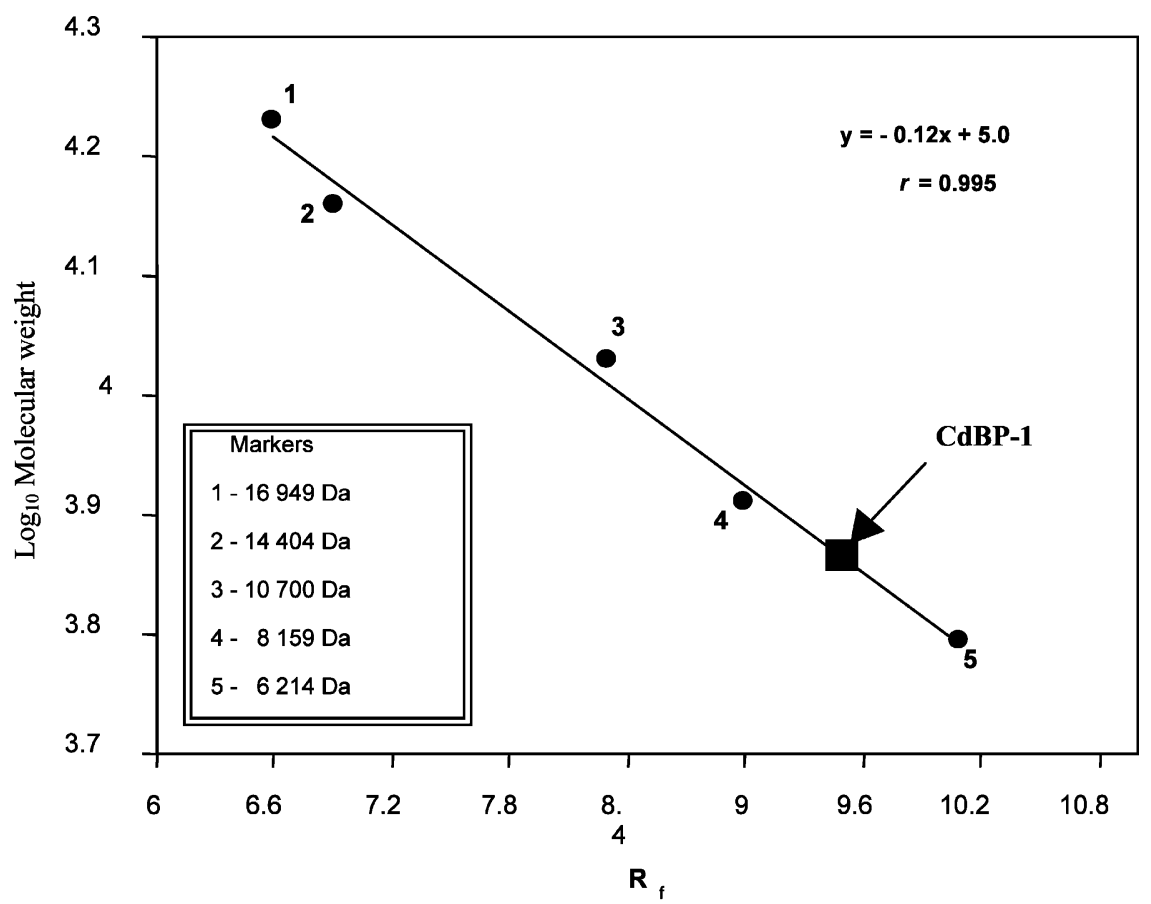

Fig. 5. Determination of molecular weight of clam MT by SDS gel electrophoresis calibrated with molecular weight markers ranging from 6214 to $16949 \mathrm{kDa}$.

dex 75 (Fig. 1) demonstrate that all the cadmium was associated with a CdMT fraction with an average apparent molecular weight of $13700 \mathrm{Da}$, which was different from the molecular weight of $7328 \mathrm{Da}$ obtained on calibrated gel SDS-PAGE electrophoresis. This discrepancy is largely reported in well-characterised MT proteins from other organisms (Mackay et al., 1993; Olafson et al., 1979; Roesijadi et al., 1989), and is attributed to their flexible (Vasak et al., 1984), nonglobular, prolate ellipsoid shape with a calculated axial ratio of 6 (Kagi et al., 1974).

Cd-MTs from the clam $R$. decussatus was separated into four components (Fig. 2). All these components were purified. They all show to bind cadmium and have a characteristic absorption spectra (with low $280 \mathrm{~nm}$ absorption and a shoulder at $254 \mathrm{~nm}$ ) consistent with the lack of aromatic residues in the amino acid composition (Fig. 4) and of $\mathrm{Cd}^{2+}$ thiolate co-ordination indicative of the presence of $\mathrm{Cd}$-thiolate clusters (Vasak et al., 1984). This absorbance profile was similar to that reported for a Cd-MT by Bernhard et al. (1983). The exact nature of this electronic transition is still under discussion. The polarographic activity measured in the fractions with high cadmium content after Superdex 75, similarly agreed with the characteristic amino acid compo-

Table 2

$\mathrm{NH}_{2}$-terminal amino acid sequence of $R$. decussatus cadmium binding proteins

$\mathrm{NH}_{2}$-terminal amino acid sequence

CdMT-1 GDPCNVAETGQCVCAQCCK

CdMT-2 GEPCN

CdMT-3 n.d.*

CdMT-4 n.d.** 
sition indicating the presence of a high cysteine (thiol) content typical of MTs (Raspor et al., 1989) and confirming the results already obtained for this species by Bebianno et al. (1993).

Based on the chain molecular weight obtained by gel SDS-PAGE electrophoresis the three clam CdMTs isolated bind a total of six to eight cadmium atoms (Table 1). This results of stoichiometry metal/chain of MT confirm the existence of a cluster identical to the one suggested for others MTs isolated and structurally characterised (Coleman, 1993).

From the $\mathrm{NH}_{2}$-terminal sequence analysis results (Table 2) only two isoforms in the digestive gland of $R$. decussatus were sequenced. It is possible that these isoforms arise due to polymorphism within the clam population as a large number of clams were required to prepare the MTs. Allelic polymorphism between clams is more likely due to the high degree of heterozygosity in invertebrates than in vertebrates. To date the highest number of isoforms found in aquatic species was in mussel M. edulis MT (at least nine Cd-induced isoforms, Mackay et al., 1993). The CdMT with a $\mathrm{NH}_{2}$-terminal blocking moiety might also be a common feature in aquatic invertebrates. Similar results were obtained for one oyster C. virginica isoform (Roesijadi et al., 1989).

As already mentioned, the function of this protein is unclear and the reason for this large number of isoforms in marine invertebrates is also not clear. Suggestions included different specificity of the promoter region of the gene (Schmidt et al., 1985), different metal-binding affinities (Winge and Miklossy, 1982) or simply the need for a large number of copies to facilitate a rapid response when necessary (Olafson et al., 1979). Considering the $\mathrm{NH}_{2}$-terminal sequence results (Table 2), the absence of methionine is consistent with other aquatic invertebrate MTs (Roesijadi et al., 1989; Mackay et al., 1993) indicating that MTs in this types of organisms are subject to $\mathrm{NH}_{2}$-terminal modifications following initial synthesis that does not occur in the mammalian MTs.

The glycine content observed for the clams MTs are unusual for mammalian MT and the similarity in the $\mathrm{NH}_{2}$-terminal of the clam MT with the

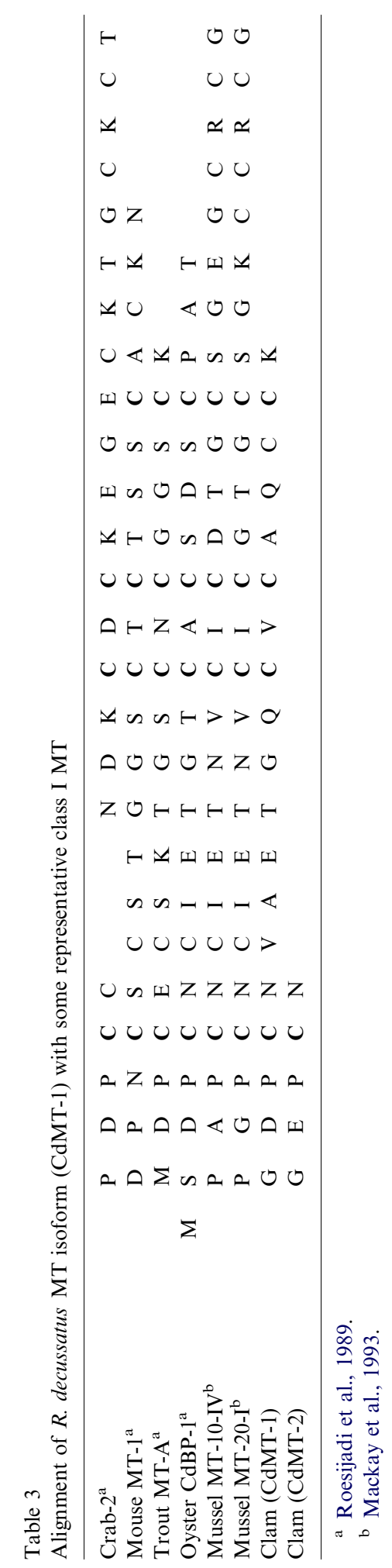


Table 4

Comparison of $\mathrm{MT} \mathrm{NH}$-terminal sequence from $R$. decussatus with other MT sequences on the basis of optimised FASTA scores, identity and length of overlapping region using the FASTA sequence comparison program (Lipman et al., 1990)

\begin{tabular}{|c|c|c|c|c|c|c|}
\hline Systematic group & Species & MT isoform & Optimised FASTA score & Identity $(\%)$ & Length of overlap (number of residues) & Reference \\
\hline \multicolumn{7}{|l|}{ Invertebrates } \\
\hline \multirow[t]{6}{*}{ Mollusca } & C. gigas & MT & 97 & 77 & 17 & a \\
\hline & C. virginica & MT & 93 & 59 & 17 & Unger et al. (1991) \\
\hline & M. edulis & MT10-IV & 73 & 41 & 22 & Mackay et al. (1993) \\
\hline & & MT20-I & 77 & 41 & 22 & Mackay et al. (1993) \\
\hline & Littorina littorea & MT & 62 & 47 & 17 & a \\
\hline & P. viridis & MT & 73 & 50 & 16 & Khoo and Patel (1999) \\
\hline Crustacea & Homarus americanus & CuMT-I & 55 & 43 & 16 & Brouwer et al., (1989) \\
\hline \multicolumn{7}{|l|}{ Vertebrates } \\
\hline \multirow{5}{*}{ Fish } & Carassius auratus & MT & 88 & 50 & 18 & Chan (1994) \\
\hline & Rutilus rutilus & MT & 90 & 50 & 18 & a \\
\hline & Danio rerio & MT & 88 & 50 & 18 & a \\
\hline & Thermarces cerberus & MTA & 85 & 44 & 18 & a \\
\hline & Barbatula barbatula & MT & 86 & 44 & 18 & Kille et al. (1991) \\
\hline Bird & Columba livia & MT-1 & 62 & 46 & 15 & Lin et al. (1990) \\
\hline
\end{tabular}

MT - metallotionein. Information was derived from a search of the SWISS-PROT data base.

${ }^{a}$ Sequences obtained from NCBI data bank with the accession numbers: CAC82788 for C. gigas, AAK56498 for L. littorea, P80593 for $R$. rutilus, NP 571150 for $D$. rerio, CAA65932 for T. cerberus. 
oyster MT may support that this might be a molluscan variety of MT. The clam MT occurred in at least four isoforms whose only difference appear to be the presence in one of them of a blocked $\mathrm{NH}_{2}$-terminal similarly to what has happened in the oyster C. virginica (Unger et al., 1991). In mussels glycine residues are also present in high amounts (around 15\%) and do not have to have any specific sequence relationship with other amino acid and are apparently randomly distributed throughout the sequence (Mackay et al., 1993).

A comparison between $R$. decussatus $\mathrm{NH}_{2}-$ terminal MT with those of other species so far reported was made on the basis of optimised FASTA scores (Lipman et al., 1990) and showed a higher degree of similarity with the oyster MT $\mathrm{NH}_{2}$-terminal (77\% identity for Crassostrea gigas and $59 \%$ for $C$. virginica) than with the mussels one $(41 \%$ for $M$ edulis and $50 \%$ for $P$. viridis, Table 4). As a conclusion the clam MT sequence belongs to the class I MTs, like the other molluscan MTs and more recently to the family molluscs MT. Interestingly, molluscan MTs appear to be more closely related to vertebrate MTs than to those from other invertebrate phyla (Table 3; Unger et al., 1991; Dallinger et al., 1993).

A consensus alignment of clam MT $\mathrm{NH}_{2}-$ terminal sequence with some representative class I MTs, shown in Table 4, highlights the alignment of cysteine residues amongst this group of MTs. The percentage identity apart from the cysteine residues in this portion of the protein is relatively low. This is the most variable region of the mammalian molecules (Kagi and Kojima, 1987a,b) indicating few functional restraints on residues other than cysteine in this domain which is possible due to the lack of any recognisable secondary structure. In general, the most functionally important amino acids are conserved to a high degree.

\section{Conclusions}

It could be concluded that clam CdMT is a MT that belongs to the class I MT family and recently to the mollusc MT family. The positions of the cisteinyl residues with the oyster and mussels MT (Table 3) were highly conserved. Ion-exchange chromatography showed the presence of four low molecular weight cadmium-binding proteins in $R$. decussatus. Based on cadmium content and UV spectra, there are four different isoforms of $R$. decussatus $\mathrm{MT}$ but the results of $\mathrm{NH}_{2}$-terminal sequence were conclusive in only two of them. There is also evidence in this species of polymorphism as previous reported for mussel MTs (Mackay et al., 1993) which can be a characteristic amongst invertebrate MTs.

Further investigation of the number and inducibility of the isoforms as well as metal binding characteristics will be necessary for the use of clam MTs as biomarkers.

\section{Acknowledgements}

The authors would like to thank Dr Filomena Rita for her helpful assistance in the experiments.

\section{References}

Bebianno, M.J., Langston, W.J., 1989. Quantification of metallothioneins in marine invertebrates using differential pulse polarography. Port. Electrochim. Acta 7, 59-64.

Bebianno, M.J., Nott, J.A., Langston, W.J., 1993. Cadmium metabolism in the clam Ruditapes decussata: the role of metallothioneins. Aquat. Toxicol. 27, 315-334.

Bebianno, M.J., Serafim, M.A., Rita, M.F., 1994. Involvement of metallothionein in cadmium accumulation and elimination in the clam Ruditapes decussata. Bull. Environ. Contam. Toxicol. 53, 726-732.

Berger, B., Hunziker, P.E., Hauer, C.R., Birchler, N., Dallinger, R., 1995. Mass spectrometry and amino acid sequencing of two cadmium-binding metallothionein isoforms from the terrestrial gastropod Arianta arbustorum. Biochem. J. 311, 951-957.

Bernhard, W., Good, M., Vasak, M., Kagi, J.H.R., 1983. Spectroscopic studies and characterization of metallothioneins containing mercury, lead and bismuth. Inorg. Chim. Acta Bioinorg. Chem. 79, 154-159.

Blum, H., Beier, H., Gross, H.J., 1987. Improved silver staining of plant proteins, RNA and DNA in polyacrylamide gels. Electrophoresis 8, 93-99.

Braun, W., Vasak, M., Robbins, A.H., Stout, C.D., Wagner, G., Kagi, J.H.R., Wuthrich, K., 1992. Comparison of the NMR solution structure and the X-ray crystal structure of 
rat metallothionein-2. Proc. Natl. Acad. Sci. USA 89, $10124-10128$

Brouwer, M., Winge, D.R., Gray, W.R., 1989. Structural and functional diversity of copper metallothioneins from the american lobster Homarus americanus. J. Inorg. Biochem. 35, 289-303.

Chan, K.M., 1994. PCR-cloning of the goldfish and tilapia metallothionein complementary cDNAs. Biochem. Biophys. Res. Commun. 205, 368-374.

Chubatsu, L.S., Meneghini, R., 1993. Metallothionein protects DNA from oxidative damage. Biochem. J. 291, 193-198.

Coleman, J.E., 1993. Cd-113 nuclear magnetic resonance applied to metalloproteins. Methods Enzymol. 227, 16-43.

Dabrio, M., Rodriguez, A.R., Bordin, G., Bebianno, M.J., De Ley, M., Sestakova, I., Vasak, M., Nordberg, M., 2002. Recent developments in quantification methods for metallothionein. J. Inorg. Biochem. 88, 123-134.

Dallinger, R., Berger, B., Hunziker, P.E., Bircherl, N., Hauer, C.R., Kagi, J.H.R., 1993. Purification and primary structure of snail metallothionein-similarity of the N-terminal sequence with histones. Eur. J. Biochem. 216, 739-746.

Hammer, D.H., 1986. Metallothionein. Annu. Rev. Biochem. $55,913-951$.

Kagi, J.H.R., 1993. Evolution, structure and chemical reactivity of class I metallothioneins: an overview. In: Suzuki, K.T., Imura, N., Kimura, M. (Eds.), Metallothionein III: Biological Roles and Medical Implications. Birkhauser Verlag, Basel, pp. 29-55.

Kagi, J.H.R., Kojima, J., 1987a. Chemistry and biochemistry of metallothionein. In: Kagi, J.H.R., Kojima, Y. (Eds.), Metallothionein II. Birkhauser Verlag, Basel, pp. 25-61.

Kagi, J.H.R., Kojima, J., 1987b. Chemistry and biochemistry of metallothionein. Experientia 52 (Suppl.), 35-61.

Kagi, J.H.R., Shaffer, A., 1988. Biochemistry of metallothionein. Biochemistry 27, 859-8515.

Kagi, J.H.R., Himmelhoch, S.R., Whanger, P.D., Bethune, J.L., Valle, B.L., 1974. Equine hepatic and renal metallothioneins. Purification, molecular weight, amino acid composition, and metal content. J. Biol. Chem. 249, 3537-3542.

Kille, P., Stephens, P.E., Kay, J., 1991. Elucidation of cDNA sequences for metallothioneins from rainbow trout, stone loach and pike liver using the polymerase chain reaction. Biochem. Biophys. Acta 1089, 407-410.

Khoo, H.W., Patel, K.H., 1999. Metallothionein cDNA promoter, and genomic sequences of the tropical green mussel, Perna viridis. J. Exp. Zool. 284, 445-453.

Langston, W.J., Bebianno, M.J., Burt, G.R., 1998. Metal handling strategies in molluscs. In: Langston, W.J., Bebianno, M.J. (Eds.), Metal Metabolism in the Aquatic Environment. Chapman and Hall, pp. 219-272.

Lin, L.Y., Lin, W.C., Huang, P.C., 1990. Pigeon metallothionein consists of two species. Biochem. Biophys. Acta 1037, $248-255$.

Lipman, D.J., Myers, E.W., Miller, W., Gish, W., Altschul, S.F., 1990. Basic local alignement search tool. J. Mol. Biol. $215,403-410$.
Mackay, E.A., Overnall, J., Dunbar, B., Davidson, I., Hunziker, P.E., Kagi, J.H.R., Fothergill, J.E., 1993. Complete amino acid sequences of five dimeric and four monomeric forms of metallothionein from edible mussel Mytilus edulis. Eur. J. Biochem. 218, 183-194.

Mitra, P., Pal, A.K., Basu, D., Hati, R.N., 1994. A staining procedure using coomassie brilliant blue G-250 in phosphoric acid for detection of protein bands with high resolution in polyacrylamide gel and nitrocellulose membrane. Anal. Biochem. 223, 327-329.

Narula, S.S., Brouwer, M., Hua, Y., Armitage, I.M., 1995. Three-dimensional solution structure of Callinectes sapidus metallothionein-1 determined by homonuclear and heteronuclear resonance spectroscopy. Biochemistry 34, 620-631.

Nordberg, M., 1998. Metallothioneins: historical review and state of knowledge. Talanta 46, 243-254.

Olafson, R.W., Sims, R.G., Boto, K.G., 1979. Isolation and chemical characterization of heavy metal-binding protein metallothionein from marine invertebrates. Comp. Biochem. Physiol. B 62, 407-416.

Pedersen, K.L., Pedersen, S.N., Hojrup, P., Andersen, J.S., Roepstorff, P., Knudsen, J., Depledge, M.H., 1994. Purification and characterization of a cadmium-induced metallothionein from the shore crab Carcinus maenas (L.). Biochem. J. 197, 609-614.

Raspor, B., Pavicic, J., Branica, M., 1989. Cadmium-induced proteins from Mytilus galloprovincialis, polarographic characterization and study of their interaction with cadmium. Mar. Chem. 28, 199-214.

Riek, R., Prêcheur, B., Wang, Y., MacKay, E.A., Wider, G., Guntert, P., Liu, A., Kagi, J.H.R., Wuthrich, K., 1999. NMR structure of the sea urchin (Strongylocentrotus purpuratus) metallothionein MTA. J. Mol. Biol. 291, 417428.

Robbins, A.H., McRee, D.E., Williamson, M., Collett, S.A., Xuong, N.H., Furey, W.F., Wang, B.C., Stout, C.D., 1991. Refined crystal structure of $\mathrm{Cd}, \mathrm{Zn}$ metallothionein at $2.0 \AA$ resolution. J. Mol. Biol. 221, 1269-1293.

Roesijadi, G., 1993. In: Suzuki, K.T., Imura, N., Kimura, M. (Eds.), Metallothionein III: Biological Roles and Medical Implications. Birkhauser Verlag, Basel, pp. 141-158.

Roesijadi, G., Kielland, S., Klerks, P., 1989. Purification and properties of novel molluscan metallothioneins. Arch. Biochem. Biophys. 273, 403-413.

Schmidt, C.J., Jubier, M.-F., Hamer, D.H., 1985. Structure and expression of 2 human metallothionein-I isoforms and a related pseudogene. J. Biol. Chem. 260, 7731-7737.

Unger, M.E., Chen, T.T., Murphy, C.M., Vestling, M.M., Fenselau, C., Roesijadi, G., 1991. Primary structure of molluscan metallothioneins deduced from PCR-amplified cDNA and mass spectrometry of purified proteins. Biochim. Biophys. Acta 1074, 371-377.

Vasak, M., 1991. Criteria of purity of metallothioneins. Methods Enzymol. 205, 44-47.

Vasak, M., Berger, C., Kagi, J.H.R., 1984. Dynamic structure of metallothionein. FEBS Lett. 168, 174-178. 
Wang, Y., Mackay, E.A., Kurasaki, M., Kagi, J.H.R., 1994. Purification and characterization of recombinant sea urchin metallothionein expressed in Escherichia coli. Eur. J. Biochem. 225, 449-457.

Winge, D.R., Miklossy, K.A., 1982. Domain nature of metallothionein. J. Biol. Chem. 257, 3471-3476.
Zeng, J., Heuchel, R., Schaffner, W., Kagi, J.H.R., 1991a. Thionein (apo-MT) can modulate DNA binding and transcription activation by zinc finger containing factor. FEBS Lett. 279, 310-312.

Zeng, J., Vallee, B.L., Kagi, J.H.R., 1991b. Zinc transfer from transcription factor IIIA fingers to thionein clusters. Proc. Natl. Acad. Sci USA 88, 9984-9988. 